\title{
In Vitro Studies on the Immunomodulatory Effects of Pulicaria crispa Extract on Human THP-1 Monocytes
}

\author{
Tarfa Albrahim, ${ }^{1}$ Moonerah M. Alnasser, ${ }^{2}$ Mashael R. Al-Anazi, ${ }^{3}$ Muneera D. ALKahtani, ${ }^{4}$ \\ Saad Alkahtani ${ }^{\circ},{ }^{2}$ and Ahmed A. Al-Qahtani $\oplus^{3,5}$ \\ ${ }^{1}$ College of Health and Rehabilitation Sciences, Department of Health Sciences, Clinical Nutrition, Princess Nourah Bint \\ Abdulrahman University, Riyadh, Saudi Arabia \\ ${ }^{2}$ Department of Zoology, College of Science, King Saud University, Riyadh, Saudi Arabia \\ ${ }^{3}$ Department of Infection and Immunity, Research Center, King Faisal Specialist Hospital \& Research Center, Riyadh, Saudi Arabia \\ ${ }^{4}$ Department of Biology, College of Science, Princess Nourah bint Abdulrahman University, Riyadh, Saudi Arabia \\ ${ }^{5}$ Department of Microbiology and Immunology, Alfaisal University, School of Medicine, Riyadh, Saudi Arabia
}

Correspondence should be addressed to Ahmed A. Al-Qahtani; aqahtani@kfshrc.edu.sa

Received 20 April 2020; Revised 29 June 2020; Accepted 21 July 2020; Published 26 September 2020

Guest Editor: Madhukar Saxena

Copyright ( 92020 Tarfa Albrahim et al. This is an open access article distributed under the Creative Commons Attribution License, which permits unrestricted use, distribution, and reproduction in any medium, provided the original work is properly cited.

Background. Pulicaria crispa (P. crispa) is a plant from the Compositae family that exhibits antioxidant, anti-inflammatory, antibacterial, and cytotoxic activities. Objective. The current study aimed at investigating the immunomodulatory effects of $P$. crispa extract in lipopolysaccharide- (LPS-) stimulated human monocytic THP-1 cells. Methods. To induce macrophage differentiation, THP-1 cell lines were treated with phorbol-12-myristate 13-acetate, followed by exposure to LPS with or without 50 or $100 \mu \mathrm{g} / \mathrm{ml}$ of $P$. crispa extract. The following tests were employed to test the immunomodulatory effects of the extract: MTT assay, ELISA, Western blotting analysis, cell migration and phagocytosis assays, and Annexin V staining method. Results. Exposure to $100 \mu \mathrm{g} / \mathrm{ml} \mathrm{P.} \mathrm{crispa} \mathrm{extract} \mathrm{significantly} \mathrm{reduced} \mathrm{THP-1} \mathrm{cell} \mathrm{proliferation,} \mathrm{migration,} \mathrm{and} \mathrm{phagocytosis} \mathrm{(in} \mathrm{LPS-}$ stimulated cells, but not in unstimulated cells). Moreover, the extract alone significantly reduced the rate of THP-1 cell apoptosis, while it increased the rate of late apoptosis. Molecular investigations showed that treatment with $P$. crispa extract significantly upregulated the expression of ERK1, p-MAPK, P-P38, and Bcl2, while it significantly reduced the expression of ERK5, Bax, NF- $\kappa$ B, P-NF- $\kappa$ B, CCL1, CCL2, CCL5, CCL22, CXCL1, and CXCL10. Conclusion. Pulicaria crispa extract exhibited anti-inflammatory, antiproliferative, antimigratory, and antiphagocytic effects in LPS-stimulated THP-1 cells. Future studies should investigate these mechanisms in animal models with chronic inflammatory diseases.

\section{Introduction}

Macrophages (MФs) are cells of the innate immune system that start differentiating in the human body in the second trimester of gestation. They are essential in maintaining immune homoeostasis and play several roles in initiating and regulating the immune responses to foreign antigens [1]. Generally, $M \Phi$ s were seen primarily as phagocytes that engulf bacteria and dying cells [2]; however, substantial recent evidence uncovered other functions executed by various surface and intracellular receptors of these cells. Such functions include regulation of bone remodeling [3], erythro- poiesis [4], brain development [5], iron recycling [6], and tissue regeneration [7]. M $\Phi$ s are classically divided into $\mathrm{M} 1$ and M2 cells: M1 M $\Phi$ s which exhibit proinflammatory, bactericidal, and phagocytic activities and M2 cells which are involved in tissue regeneration and regulating the immune response via interleukin- (IL-) 10 secretion [8].

The role that $M \Phi$ s play in inflammation is multifaceted [1]. Exposure to damage-associated molecular patterns (DAMPs), released from damaged cells, causes $\mathrm{M} \Phi$ s to secrete several cytokines including IL- $1 \beta$, IL-6, tumor necrosis factor- $\alpha$, and proinflammatory eicosanoids. These secreted molecules cause vasodilatation and edema, followed 
by neutrophil recruitment [9]. Further, following phagocytosis and lysis of foreign organisms, $M \Phi$ s present antigens from its surface major histocompatibility complex- (MHC-) II receptor molecules to allow T-helper cells to initiate adaptive immune response [10].

During resolution of the inflammation, some $M \Phi s$ undergo apoptosis or convert from an initial proinflammatory (M1) phenotype to a healing proresolving (M2) phenotype consistent with plasticity of myeloid cells [11]. Examples of this behavior were observed in the muscles [12] and kidneys [13]. However, $M \Phi$ s sometimes escape these destinies and become more active and with a longer lifespan [14]. The latter cells have been implicated in chronic inflammatory and autoimmune diseases [15].

Pulicaria crispa (also known as Francoeuria crispa) is a plant from the Compositae family that commonly grows in the Middle East countries, including Saudi Arabia and Egypt. Although it has been used in traditional medicine for a long time, it has become a topic of interest for medicinal research since the 1980s [16]. Previous studies have shown that $P$. crispa derivatives exert antioxidative [17], anti-inflammatory [18], and chemopreventive activities [19]. A phytochemical screening of P. crispa extract attributed these effects to the presence of coumarins, tannins, and flavonoids [18, 20].

The extracts of $P$. crispa have shown anti-inflammatory, as well as immunostimulatory effects. For example, several studies have shown antimicrobial effects for $P$. crispa extracts against Gram-negative bacteria [21-23], Mycobacteria [20, 21], Candida albicans [17], Schistosoma mansoni [24], Leishmania [25], and hepatitis B virus [26]. On the other hand, extracts from the Pulicaria species have been shown to inhibit neutrophil infiltration and alleviate oxidative stress. It was also postulated that it suppresses the generation of nitric oxide [27] and modulates the expression of intracellular adhesion molecule-1 (ICAM-1), tumor necrosis factor(TNF-) $\alpha$ [18], and prostaglandin E2 [18]. Therefore, further study of their effects on the immune system, especially at the molecular level, will be particularly insightful.

Despite the benefits of the immune inflammatory response to foreign antigens, a dysregulated immune response can lead to a wide array of chronic inflammatory conditions [28]. Several in vivo and in vitro models have been proposed to study the anti-inflammatory and immunomodulatory effects of various phytochemicals and pharmaceutical compounds. Of these models, human leukemic THP-1 monocytes have attracted attention as a valid in vitro model to investigate the molecular mechanisms of inflammation [29-31]. For example, previous studies have used this model to evaluate the anti-inflammatory effects of several phytochemicals extracted from different organisms, including Corydalis crispa, Corydalis dubia, Ajania nubigena, Meconopsis simplicifolia, Ocimum sanctum, and Uncaria tomentosa [32-34].

Owing to the scarcity of molecular research regarding the immunomodulatory effects of $P$. crispa effects, the current study was performed to utilize human THP-1 cells as an in vitro model to test the effects of their exposure to lipopolysaccharide (LPS) and P. crispa extract.

\section{Materials and Methods}

2.1. P. crispa Extract. The preparation of the extract was described in detail elsewhere [26].

2.2. Growth and Maintenance of THP-1 Cells. The human monocytic THP-1 cells were cultured in RPMI media supplemented with $10 \%$ fetal bovine serum (FBS), $100 \mathrm{IU} / \mathrm{ml}$ penicillin, $100 \mu \mathrm{g} / \mathrm{ml}$ streptomycin, and $3.7 \mathrm{~g} / \mathrm{l}$ sodium bicarbonate. The cells were maintained in $37^{\circ} \mathrm{C}$ temperature and $5 \% \mathrm{CO}_{2}$.

2.3. Differentiation of THP-1 Cells into Macrophage-Like Cells. THP-1 cells $\left(5 \times 10^{5}\right)$ were incubated with $100 \mathrm{ng} / \mathrm{ml}$ of phorbol 12-myristate 13-acetate for 48 hours. The cells were then washed with RPMI 1640 serum-free medium to eliminate undifferentiated cells.

2.4. Treatment of MФs with LPS and/or P. crispa Extract. Differentiated cells were treated with $100 \mathrm{ng} / \mathrm{ml} \mathrm{LPS}$, isolated from Escherichia coli O26:B6 bacteria (Sigma-Aldrich, St. Louis, MO, USA), alone, LPS $+50 \mu \mathrm{g} / \mathrm{ml}$ or LPS $+100 \mu \mathrm{g} / \mathrm{ml}$ of $P$. crispa extract. In some experiments, differentiated cells were treated with the extract alone $(50$ or $100 \mu \mathrm{g} / \mathrm{ml})$. The duration of the treatment was either 4 hours or 6 hours.

2.5. MTT Cell Proliferation Assay. The MTT assay kit (Abcam, Cambridge, MA, USA) was used following the manufacturer's instructions. The treated cells, at a density of 5 $\times 10^{4}$ cells/well, were incubated with either 50 or $100 \mu \mathrm{g} / \mathrm{ml}$ P. crispa extract for 1 to 8 days. After incubation with MTT reagent for three hours, the absorbance was read in the SpectraMax i3x Multi-Mode Microplate Reader (Molecular Devices, Sunnyvale, CA, USA) at $540 \mathrm{~nm}$ wavelength.

2.6. Expression Analysis by Real-Time Quantitative ReverseTranscriptase Polymerase Chain Reaction ( $q R T-P C R)$. Total RNA was extracted from treated THP-1 cells using the QIAamp RNA Blood Mini Kit (Qiagen, Hilden, Germany) following the manufacturer's instructions, followed by a double-stranded cDNA synthesis using All-in-One cDNA Synthesis SuperMix (Biotool, Houston, TX, USA). The generated cDNA was used for real-time PCR experiments using target-specific primers and probes purchased from Applied Biosystems (Foster City, CA, USA). The mRNA expression levels of studied genes were normalized to GAPDH.

2.7. Enzyme-Linked Immunosorbent Assay (ELISA). Supernatants from treated cells were collected for quantitation of secreted proteins. The DuoSet ${ }^{\circledR}$ ELISA kit (R\&D Systems, Minneapolis, MN, USA) was used to determine the quantities of IL-1 $\beta$, IL-8, CCL22, and CXCL10 following the manufacturer's instructions. Briefly, supernatants were added to wells precoated with protein-specific antibodies, incubated for 2 hours, washed three times with PBS, and incubated with Streptavidin-horseradish peroxidase (HRP) for 20 minutes. After washing, tetramethylbenzidine $(T M B)$ substrate was added for 20 minutes, the reaction was stopped, and the color intensity was measured at wavelength $450 \mathrm{~nm}$.

2.8. Western Blotting Analysis. The expression of ERK5, Bax, Bcl2, Cyclin-D1, ERK1, MEK1, NF- $\kappa$ B, P-IKB- $\alpha$, P-MAPK, 
P-NF- $\kappa$ B, and P-P38 in THP-1 cells was evaluated using the Western blotting analysis. The treated cells were lysed in the RIPA buffer, and the cellular proteins were separated on $12 \%$ SDS-polyacrylamide gel electrophoresis (PAGE). The proteins were then transferred to polyvinylidene difluoride (PVDF) membranes which were treated with $5 \%$ nonfat dry milk. The membranes were then probed with protein-specific primary antibodies overnight at $4^{\circ} \mathrm{C}$, washed, and incubated with HRP-conjugated secondary antibodies. The reaction was detected by the addition of SuperSignal West Pico 16 Chemiluminescent substrate (Thermo Fisher Scientific, Waltham, MA). The bands were visualized on a GE Amersham Imager 600, and the proteins were quantified using the ImageJ software (National Institutes of Health, Bethesda, MD).

2.9. Cell Migration Assay. Cell migration was evaluated using the CytoSelect ${ }^{\mathrm{TM}}$ 24-Well Cell Migration Assay (Cell Biolabs, San Diego, CA, USA) following manufacturer's instructions. Briefly, treated cells were incubated in a serum-free RPMI in the upper chamber. The cells were allowed to migrate to the lower chamber filled with RPMI and FBS. The chamber was then incubated for 24 hours, and the migration capability was analyzed by reading the fluorescence of the GR dye at a wavelength of excitation/emission $480 / 520 \mathrm{~nm}$.

2.10. Phagocytosis Assay. Treated THP-1 cells were incubated with Alexa Fluor 405-labeled Zymosan particles Molecular Probes (Carlsbad, CA, USA) for 1 hour in a serum-free RPMI medium at $37^{\circ} \mathrm{C}$. Cells were washed three times with PBS to eliminate noninternalized fluorescent beads. The cells were analyzed by measuring the absorbance at OD of $405 \mathrm{~nm}$.

2.11. Apoptosis Assay. Apoptosis was measured in treated cells by flow cytometry using Annexin V/propidium iodide double-staining as described before [35, 36], and the analysis was performed in FACScan equipped with the Cell Quest software (Becton Dickinson, Cockeysville, MD, USA).

2.12. Statistical Analysis. Data generated from the aforementioned assays were expressed as mean \pm standard error of mean and were presented in bar graphs with error bars. To compare the groups in, $t$ test was used. A $p$ value was considered significant if less than 0.05 .

\section{Results}

3.1. The Effects of Pulicaria crispa Extract on THP-1 Cell Proliferation. To assess the effects of P. crispa extract on THP-1 cell proliferation, MTT assay was used by incubating the cells with 50 and $100 \mu \mathrm{g} / \mathrm{ml}$ of the extract for 8 days. Analysis of the change in proliferation of the cells showed that while the vehicle control (DMSO) did not produce any significant difference in THP-1 cell proliferation in comparison to control monocytes, both concentrations of $P$. crispa extract significantly reduced the proliferation of the cells at each time point $(p=0.01)$ (Figure 1$)$.

3.2. The Effects of P. crispa Extract on mRNA Expression in THP-1 Cells. To evaluate the mRNA expression of CCL2, CCL5, and TNF- $\alpha$ in THP- 1 cells exposed to LPS or different

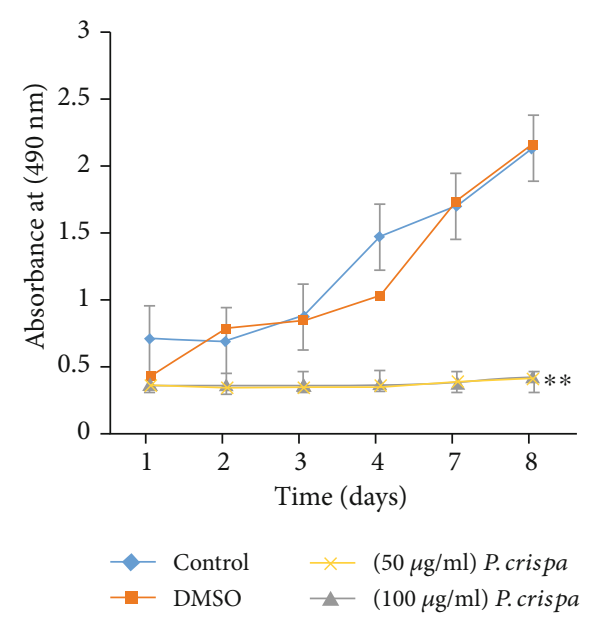

FIgUre 1: The effect of $P$. crispa extract on proliferation of THP-1 cells. The $y$-axis shows absorbance at $490 \mathrm{~nm}$ after incubation of cells treated with DMSO alone, $50 \mu \mathrm{g} / \mathrm{ml}$ or $100 \mu \mathrm{g} / \mathrm{ml}$ of $P$. crispa extract relative to untreated cells (control). $* * p$ value $<0.01$ (treatment vs. control). Values represent the mean of three different experiments done in triplicate \pm SEM for each time point tested. Statistical analysis was performed using the $t$ test.

concentrations of $P$. crispa extract, we used the qRT-PCR analysis. Exposure of cells to $100 \mathrm{ng} / \mathrm{ml}$ LPS at 4 and 6 hours significantly increased mRNA expression of CCL2 and CCL5 in a time-dependent manner $(p=0.001)$. However, treatment of LPS-exposed cells with P. crispa extract at 50 and $100 \mu \mathrm{g} / \mathrm{ml}$ was associated with a significant decrease in CCL2 and CCL5 expression in comparison to LPS alone $(p=0.001)$ (Figures 2(a) and 2(b)). On the other hand, treatment of THP-1 cells with $P$. crispa extract alone resulted in a significant increase in mRNA expression of TNF- $\alpha$ at 4 and 6 hours $(p \leq 0.01)$ (Figure 2(c)).

3.3. Protein Array Expression Analysis. Protein array was used to simultaneously detect expression of several proteins in treated cells. Comparison of control cells to cells treated with $100 \mathrm{ng} / \mathrm{ml}$ LPS showed significantly higher expression of ICAM1/CD54 $(p=0.01)$ and CCL2/MCP1 $(p=0.03)$, as well as significantly lower expression of IL1ra/IL1F3 ( $p=$ $0.004)$. However, no statistically significant differences were observed with regard to MIF, IL8, CCL1, MIP1a/MIP1b, CCL5/RANTES, and CXCL1/GROa (Figure 3(a)). In contrast, LPS-exposed cells treated with $100 \mu \mathrm{g} / \mathrm{ml} P$. crispa extract showed significant reductions with regard to CCL1 and CXCL1/GROa expression $(p<0.05)$. In addition, a significant increase in CCL5/RANTES, ICAM-1/CD54, and IL8 was observed. No significant differences were detected in the expression of MIF, IL1ra/IL1F3, and MIP-1a/MIP-1b (Figure 3(b)).

3.4. ELISA Assay Results. ELISA assay was used to confirm the results obtained by the protein array analysis. The supernatants of cultured cells were harvested after six hours of stimulation. The analysis of cells exposed to LPS only showed significant increase in the production of CCL22 $(p=0.03)$ and CXCL10 $(p=0.001)$ in comparison to control cells. On the other hand, LPS-exposed cells treated with P. crispa 


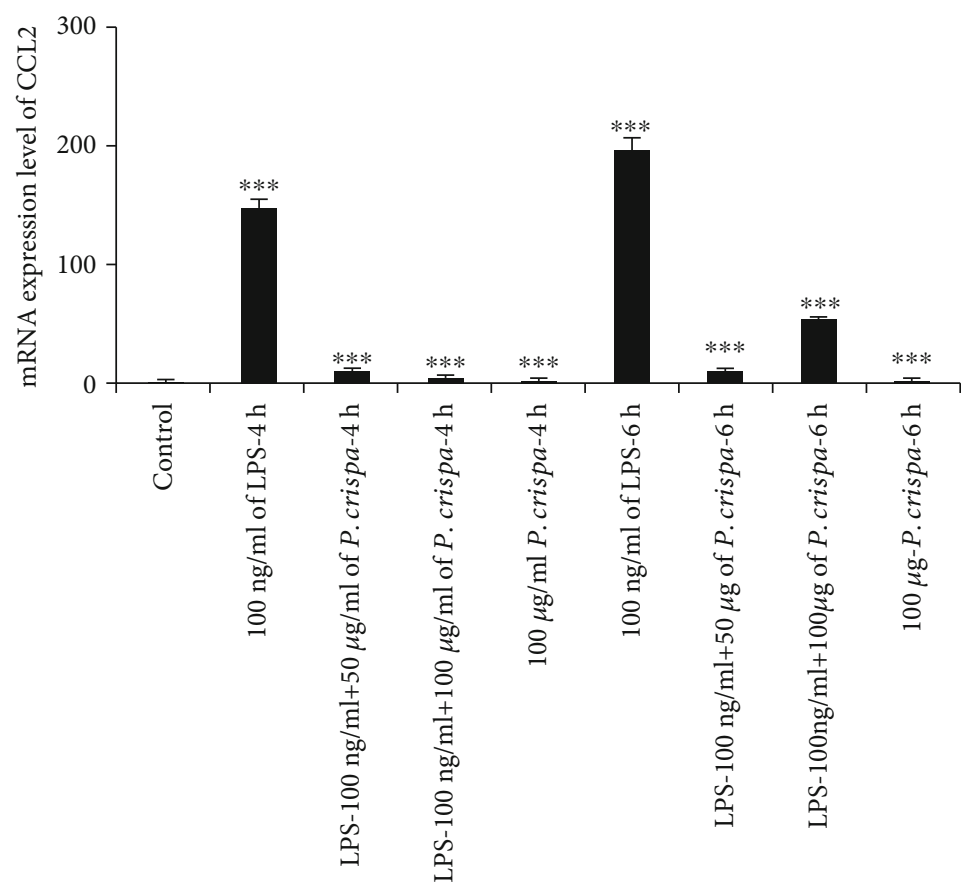

(a)

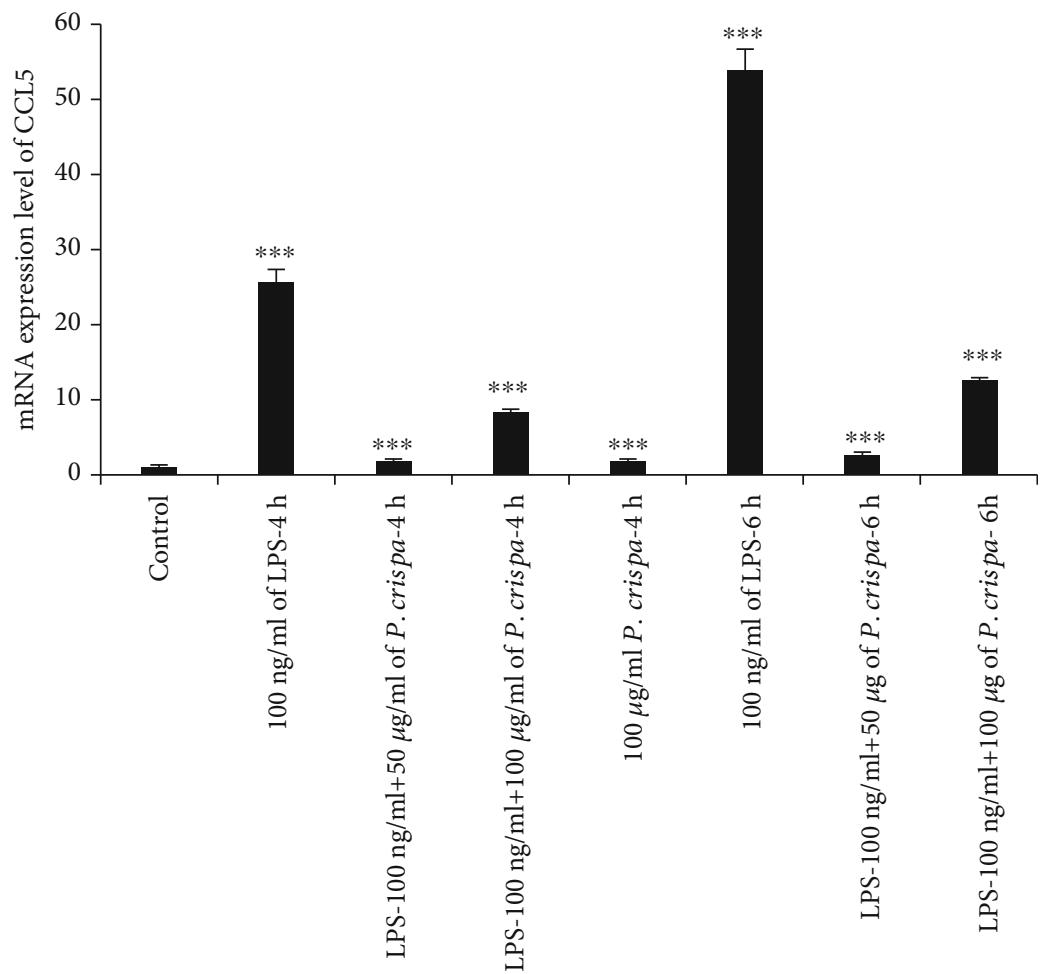

(b)

Figure 2: Continued. 


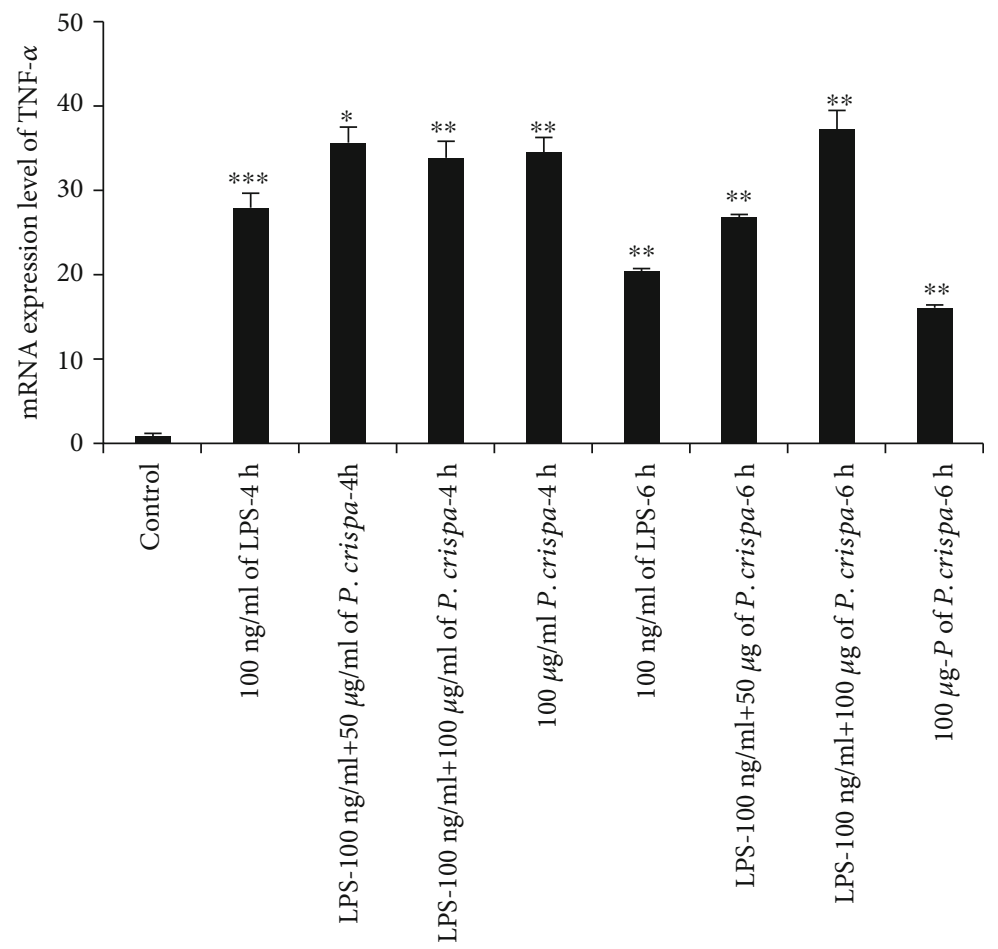

(c)

Figure 2: qRT-PCR analysis for the expression of (a) CCL2, (b) CCL5, and (c) TNF- $\alpha$. The mRNA expression levels were normalized with GAPDH. Control cells were compared with LPS-treated cells. All other cells with different treatments were compared with LPS-treated cells. The data were expressed as mean \pm standard error done in triplicate for three independent experiments. Statistical significance was established using the $t$ test. $*<0.05 ; * *<0.01 ; * * *<0.001$

extract showed significant reduction in the production of CCL22 and CXCL10 $(p=0.001)$ (Figures 4(a) and 4(b)).

3.5. Western Blotting Analysis. The expression of 11 cell survival, apoptosis, and inflammatory proteins was measured through Western blotting analysis. In comparison to nontreated cells, LPS-exposed cells showed significant overexpression of ERK5, p-NF- $\kappa \mathrm{B}$, and p-P38, as well as significant decreased expression of Bcl2, Bax, MEK1, ERK1, P-IKB- $\alpha$, and NF- $\kappa$ B. However, the expression of p-MAPK and Cyclin-D1 could not be detected in LPS-exposed cells (Figure 5). In contrast, LPS-exposed cells treated with $100 \mu \mathrm{g} / \mathrm{ml} \mathrm{P}$. crispa extract showed significant downregulation of ERK5, Bax, P-IKB- $\alpha$, and NF- $\kappa \mathrm{B}$, as well as upregulation of $\mathrm{Bcl} 2$, ERK1, p-MAPK, and p-P38 in comparison to LPS only-treated cells. Of note, the expression of MEK1, P$\mathrm{NF}-\kappa \mathrm{B}$, and Cyclin-D1 could not be detected in cells treated with LPS $+P$. crispa extract (Figure 5).

3.6. Cell Migration Assay. To assess the effect of P. crispa extract on the ability of THP-1 cell to respond to external stimuli, cell migration assay was used. The analysis showed that LPS-exposed cells were not significantly different from untreated control cells $(p=0.279)$. However, cells treated with $P$. crispa alone or in combination with LPS showed significantly reduced $(p<0.0001)$ cell migration capability in comparison to cells treated with LPS alone (Figure 6).
3.7. Phagocytosis Assay. The results of the phagocytosis assay showed that LPS-exposed THP-1 cells exhibited significantly less phagocytic activity than control untreated cells $(p<$ $0.0001)$. Further, the addition of $P$. crispa extract to LPSexposed cells reduced their phagocytic activity $(p<0.0001)$. However, THP-1 cells treated with $P$. crispa extract alone exhibited significantly higher phagocytic activity than cells treated with LPS alone $(p<0.0001)$ (Figure 7$)$.

3.8. Flow Cytometry-Based Detection of Apoptosis. This assay was conducted using Annexin V/PI double-staining method. As shown in Figure 8 and Table 1, the majority (>90\%) of monocyte cells and LPS-treated THP-1 cells remained viable with no statistically significant difference in both groups with regard to apoptotic and late apoptotic cells $(p=0.77)$. However, exposure of cells to $P$. crispa extract significantly decreased the number of apoptotic cells and increased the number of late apoptotic cells in comparison to control cells $(p=015)$. In comparison to LPS-treated cells, THP-1 cells treated with both LPS and P. crispa extract did not show significant differences in the percentage of apoptotic and late apoptotic cells $(p=0.77)$.

\section{Discussion}

Persistent activation of $\mathrm{M} \Phi$ s has been implicated in several chronic inflammatory and autoimmune diseases [37]. 
(a1)

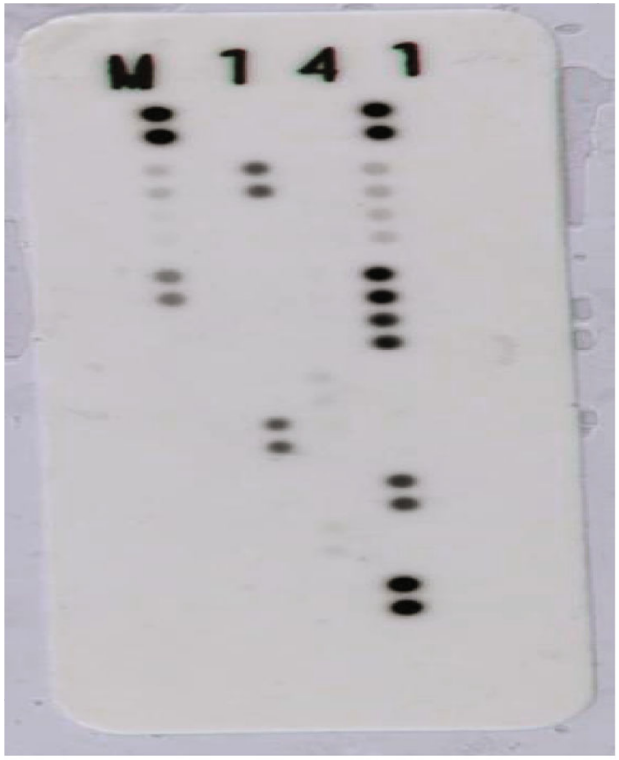

(a2)

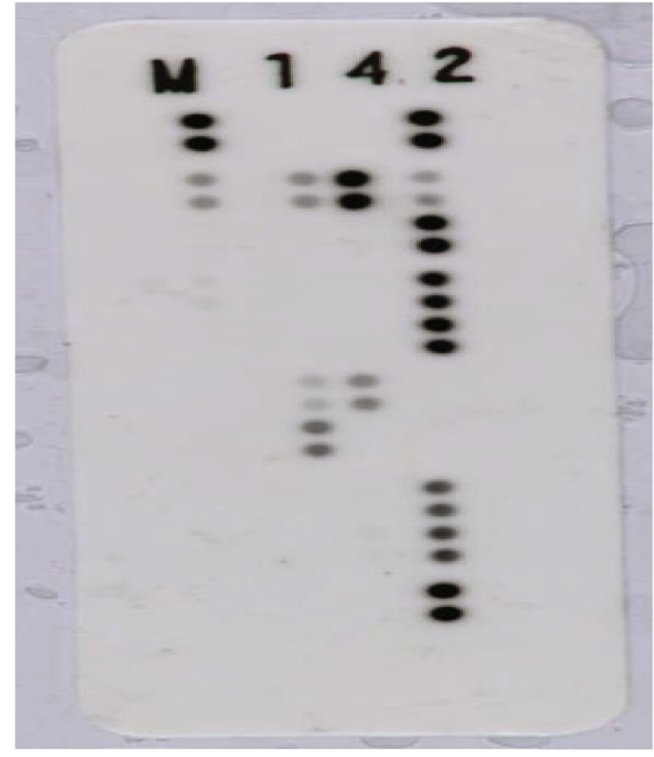

(a3)

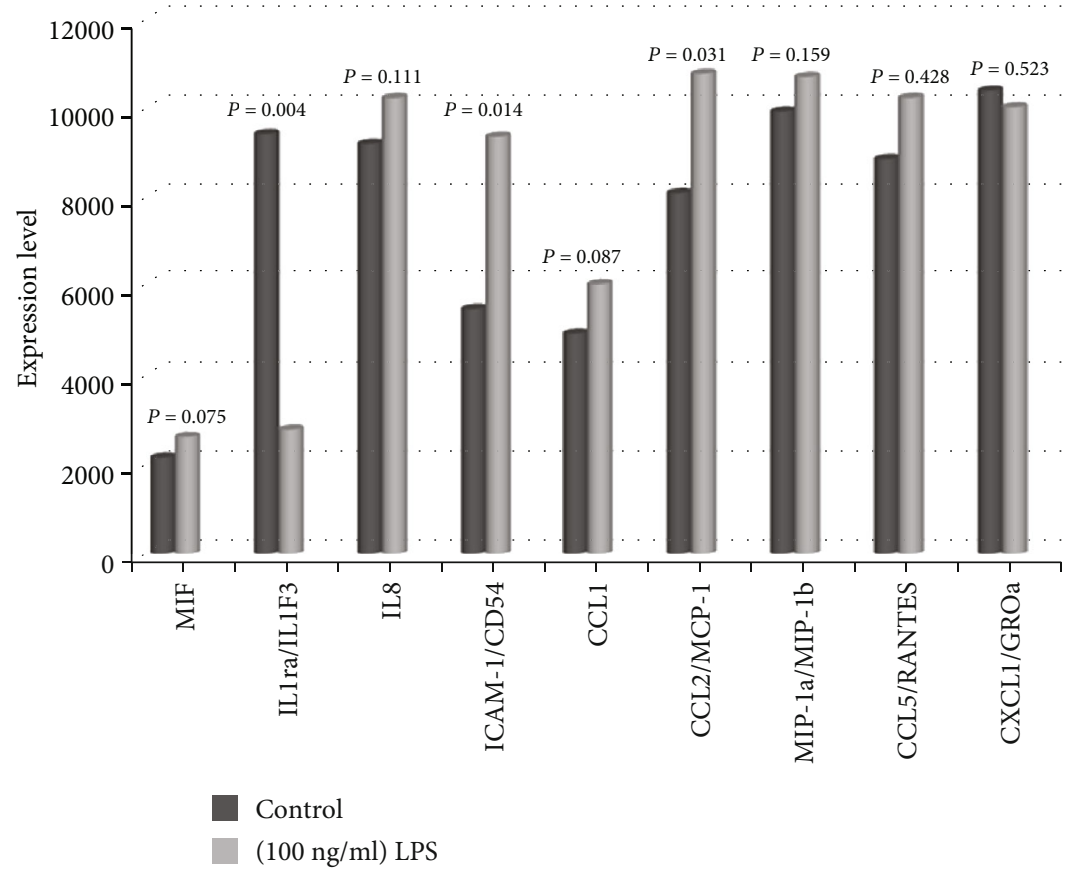

(a)

Figure 3: Continued. 
(b1)

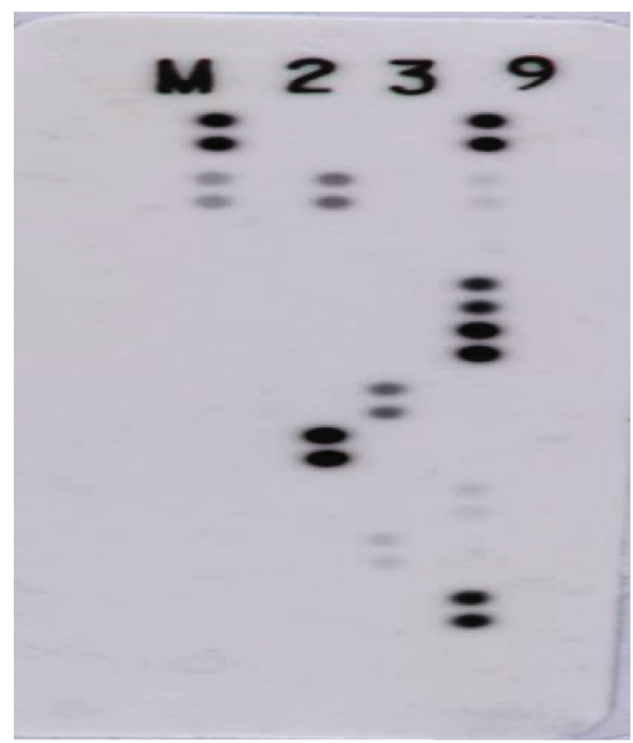

(b2)

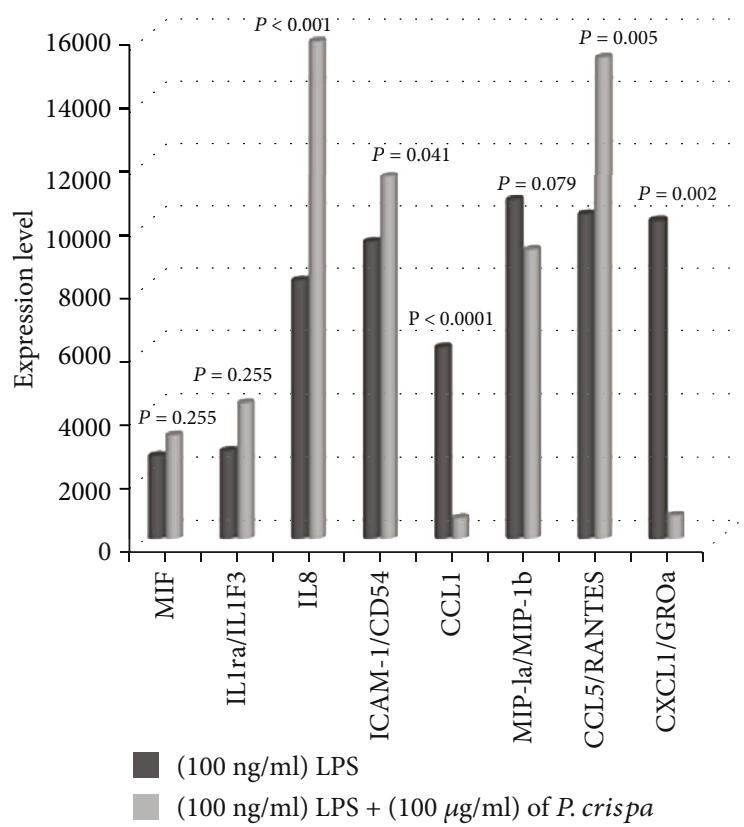

(b)

Figure 3: Protein expression array analysis. (a) Control THP-1 cells (a1); cells treated with (100 ng/ml) of LPS (a2); histograms comparing the protein array expression results from controls and THP-1 cells treated $100 \mathrm{ng} / \mathrm{ml}$ of LPS (a3). (b) Cells treated with B2 B1 25 (100 ng/ml) of LPS $+100 \mu \mathrm{g} / \mathrm{ml}$ of $P$. crispa (b1); graphical representation of LPS-treated cells (shown in a2) compared with cells treated with LPS $+P$. crispa extract (b2). Statistical significance was established using the $t$ test.

MФs under prolonged stimulation secrete large quantities of proinflammatory and chemotactic molecules. These cells also become more resistant to apoptosis [38]. Here, we used an in vitro model (THP-1 human monocytes) to simulate activated macrophages during an inflammatory response.

To discuss our results, some physiological perspective is needed to be considered. Activated $M \Phi$ s usually exhibit increased expression of molecules involved in proinflammatory signals such as NF- $\kappa \mathrm{B}$. This protein is essential in the pathway that increases the production of some interleukins, such as IL-1, IL6, and TNF- $\alpha$ [39]. Furthermore, activated macrophages orchestrate the immune response by recruiting other cells into the inflammation area through chemotactic proteins, including CCL1, CCL2, CC5, CCL22, CXCL1, and CXCL10 [40]. Inside activated macrophages, the transcriptional program shifts in favor of prolonged survival, increased proliferation, and enhanced migration [41]. In this study, we further investigated these mechanisms and evaluated the role of $P$. crispa extract in modulating these functions in $\mathrm{M} \Phi$ s. 


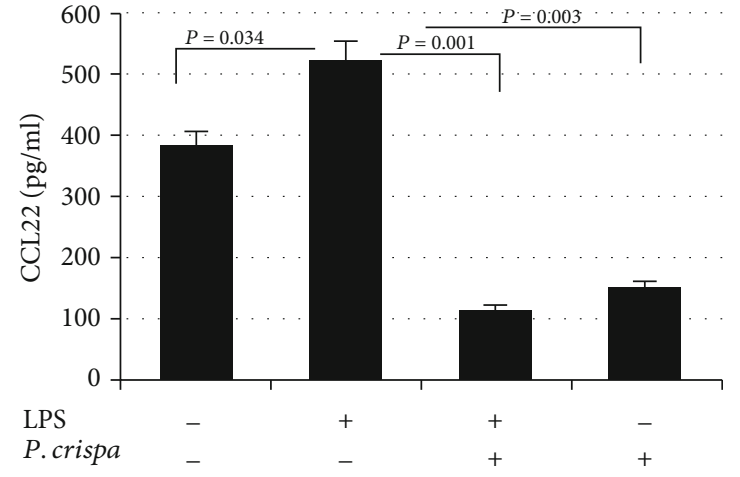

(a)

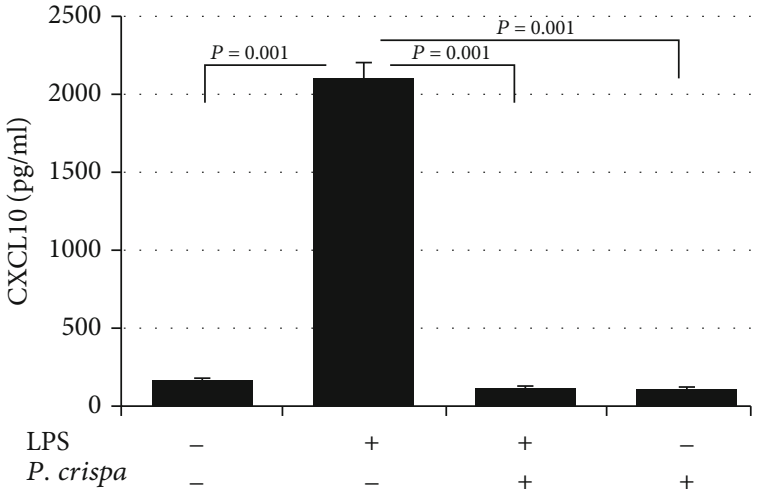

(b)

FIGURE 4: ELISA analysis of THP-1 cells after stimulation with LPS $(100 \mathrm{ng} / \mathrm{ml})$ with or without $P$. crispa extract (100 $\mu \mathrm{g} / \mathrm{ml})$. The expressions of CCL22 (a) and CXCL10 (b) are detected. Culture supernatants were harvested 6 hours after stimulation and processed for ELISA. All samples were processed in triplicate for three independent experiments \pm SEM. Statistical significance was established using the $t$ test.

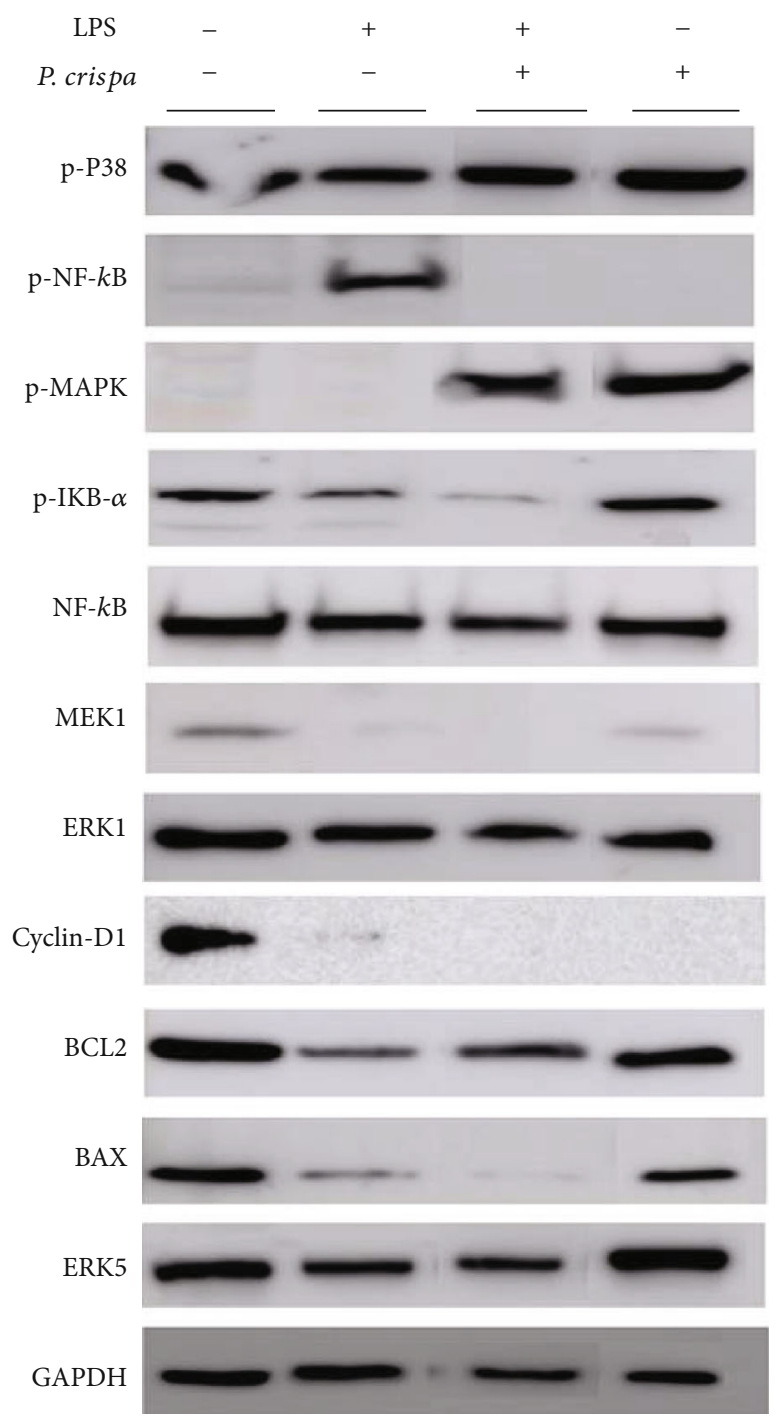

(a)

Figure 5: Continued. 

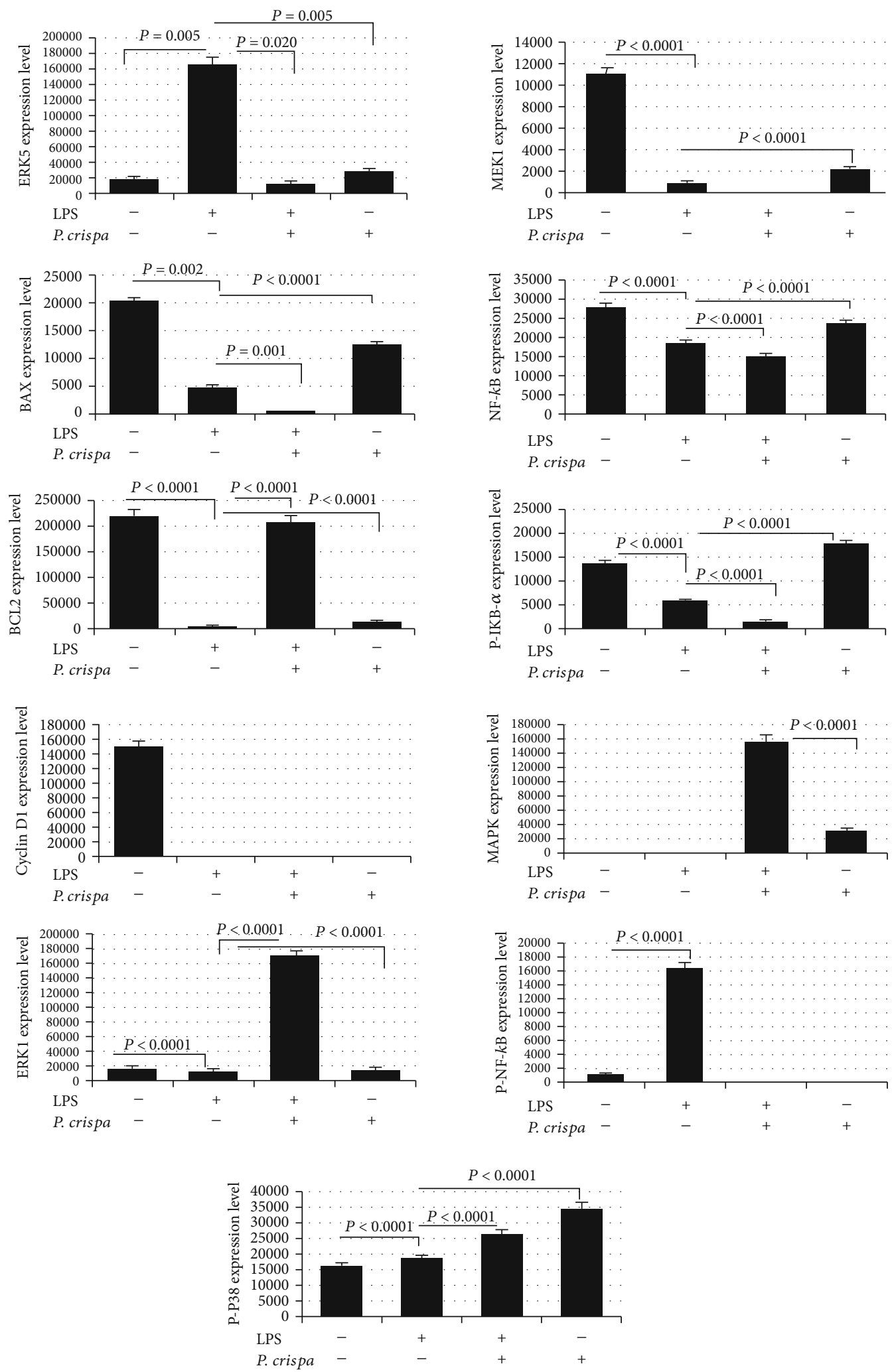

(b)

FIGURE 5: Expression analysis of proteins in THP-1 cells. (a) Western blot analysis and (b) densitometric analysis of the expression of ERK5, BAX, BCL2, Cyclin-D1, ERK1, MEK1, NF- $\kappa$ B, P-IKB- $\alpha$, P-MAPK, P-NF- $\kappa$ B, and P-P38 proteins. Cells were either untreated (control), treated with $100 \mathrm{ng} / \mathrm{ml}$ of LPS, treated with $100 \mathrm{ng} / \mathrm{ml}$ of LPS $+100 \mu \mathrm{g} / \mathrm{ml}$ of $P$. crispa extract, or treated with $100 \mu \mathrm{g} / \mathrm{ml}$ of $P$. crispa extract alone. All data are expressed as mean \pm SEM. All samples were processed in triplicate in three independent experiments. Statistical significance was established using the $t$ test. 


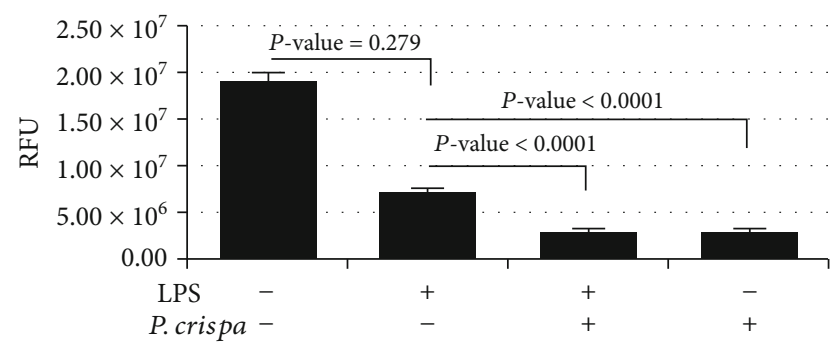

Figure 6: Migratory potential of THP-1 cells. Cells were treated with LPS $(100 \mathrm{ng} / \mathrm{ml})$ in the presence or absence of $P$. crispa extract $(100 \mu \mathrm{g} / \mathrm{ml})$. Migration capability of cells was quantified by cell migration assay. Values represent the mean of triplicate experiments done in triplicate for each time point tested. Statistical significance was established using the $t$ test. RFU: relative fluorescence units.

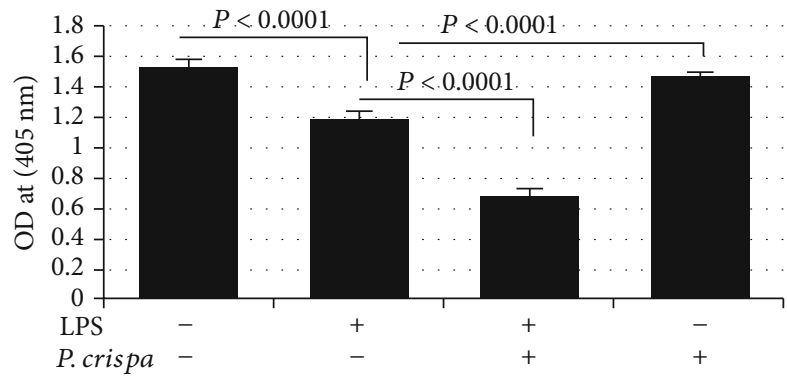

FIGURE 7: Phagocytosis assay using Zymosan particles. THP-1 cells were treated with LPS $(100 \mathrm{ng} / \mathrm{ml})$ and/or $P$. crispa extract $(100 \mu \mathrm{g} / \mathrm{ml})$. Values represent the mean of triplicate experiments done in triplicate for each time point tested. Statistical significance was established using the $t$ test

Several studies have documented that biochemical constituents, such as Alkaloid, Flavonoids, and Terpenoids, in the extract of $P$. crispa might be associated with antimicrobial and anti-inflammatory activity [20,22]. Another study found that organic constituents from $P$. undulata significantly promoted apoptosis in hepatocellular carcinoma (HCC) HepG2 cells and elevated the expression of miR-34a. Furthermore, the extract enhanced the caspase $3 / 9$ and proapoptotic $\mathrm{p} 53$ protein expression with plummeting of B-cell lymphoma-2 protein expression. Therefore, the antitumor activity of $P$. crispa through regulation of $\mathrm{p} 53 / \mathrm{B}$-cell lymphoma-2/caspases signaling pathway in the HCC HepG2 cells by overexpressing miR-34a is suggested. Such an antitumor effect might be attributed to the presence of triterpenoids and coumarins [42]. Also, Foudah et al. reported noticeable antioxidant and antimicrobial properties, and this could be owing to the presence of flavonoids, phenols, and tannins in the methanol extract of $P$. crispa plant [17].

Overall, this study showed that treatment of LPSstimulated cells with 50 and $100 \mu \mathrm{g} / \mathrm{ml}$ of $P$. crispa extract inhibited THP-1 cell proliferation, migration, and phagocytosis and altered the expression of several inflammatoryand cell survival/apoptosis-related proteins. To our knowl- edge, this is the first in vitro study to evaluate the immunomodulatory and anti-inflammatory effects of $P$. crispa in LPS-stimulated human THP-1 cells.

First, results from the MTT assay showed that both concentrations of $P$. crispa extract inhibited THP-1 cell proliferation. In parallel, downregulation of ERK5 and lack of MEK1 and Cyclin-D expression were observed in treated cells. ERK5 is a member of the MAPK family that responds to extracellular stimuli, such as stress and growth factors, to regulate cell proliferation and differentiation via its downstream targets including AKT serine-threonine protein kinase and myocyte enhancer factor [43]. Downregulation of this MAPK protein may explain the observed proliferation inhibition. In addition, the lack of MEK1, another MAPK protein involved in cell growth and proliferation, [44] and Cyclin-D (a cell cycle regulator [45] expression in P. crispa-exposed cells could explain the ability of the extract's constituents to suppress the intracellular proliferation signaling pathways. However, flow cytometry plots showed a large increase in necrotic cells following treatment with extract, which is also a sign of potential toxicity of $P$. crispa extract.

Interestingly, we also observed the increased expression of prosurvival (ERK1, MAPK, and P-P38) and antiapoptotic (Bcl2) proteins in THP-1 cells, exposed to P. crispa extracts. Activated ERK-1 activates the MAPK signal transduction pathway, which regulates cell cycle progression and survival [46]. Moreover, previous studies have shown that phosphorylated-p38 (P-P38) expression is linked to enhanced cell survival in normal and malignant cells [47, 48]. In parallel, the Annexin V staining method showed that exposure to $P$. crispa extract alone reduces the frequency of THP-1 cell apoptosis yet increases the frequency of late apoptosis. This discrepancy may be caused by a shift in the expression pattern after exposure to the P. crispa extract.

Another interesting finding was the ability of $P$. crispa extract to inhibit the migration of stimulated THP-1 cells. Molecular investigations revealed supporting results, i.e., treatment with $P$. crispa extract significantly downregulated the expression of CCL1, CCL2, CCL5, CCL22, CXCL1, and CXCL10 (all are known chemoattractant proteins) [49] in human THP-1 cells. These chemokines are produced by macrophages, and their function is to recruit leukocytes to the inflammation site. Of interest, it has been shown that $P$. crispa extract ameliorates leucocytes infiltration [27]; however, the current study is the first to focus on the molecular mechanisms underlying these cellular changes. No significant effects were observed with regard to ICAM1 expression upon $P$. crispa extract exposure, which may indicate that the extract constituents may inhibit the cellular migration, but their effects on leukocyte adhesion and cell-to-cell interactions are not significant [50].

In addition, the $P$. crispa extract showed multiple antiinflammatory effects in the present study. First, the significant reduction in NF- $\kappa \mathrm{B}$ and P-NF- $\kappa \mathrm{B}$ expression in LPSstimulated cells occurred after treatment with $100 \mu \mathrm{g} / \mathrm{ml}$ of the extract. Pereira and colleagues showed that inhibiting ERK5 suppresses the NF- $\kappa$ B signaling pathway [51]. Another study by Kloster et al. reported that MEK signaling is important for activating NF- $\kappa \mathrm{B}$ signaling [52]. The observation that 

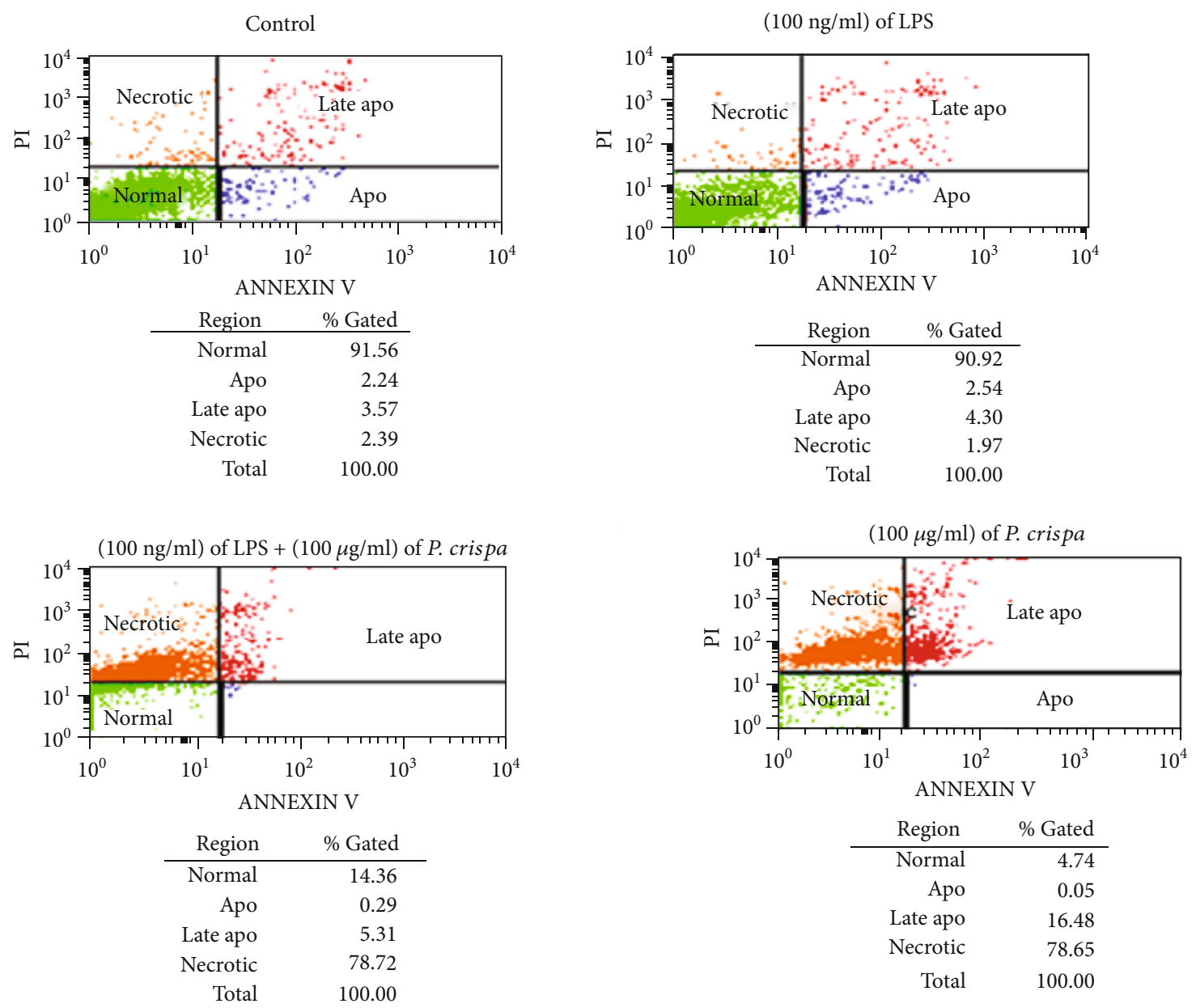

FIGURE 8: Flow cytometry using Annexin V staining method to analyze apoptosis in THP-1 cells. Analysis of apoptosis in the cells exposed to $100 \mathrm{ng} / \mathrm{ml} \mathrm{LPS} \mathrm{and/or} 100 \mu \mathrm{g} / \mathrm{ml} \mathrm{P.} \mathrm{crispa} \mathrm{extract.} \mathrm{Cells} \mathrm{that} \mathrm{were} \mathrm{propidium} \mathrm{iodide} \mathrm{(PI)} \mathrm{negative} \mathrm{and} \mathrm{Annexin} \mathrm{V} \mathrm{negative} \mathrm{are} \mathrm{considered}$ healthy, cells, PI negative and Annexin V positive cells are considered apoptotic, and cells that are positive to both PI and Annexin V considered necrotic. $*$ indicates significance.

Table 1: Flow cytometry using Annexin V staining method to analyze apoptosis in THP-1 cells.

\begin{tabular}{|c|c|c|c|}
\hline & Control & $(100 \mathrm{ng} / \mathrm{ml})$ of LPS & $p$ value \\
\hline Apoptosis & 2.24 & 2.54 & \multirow{2}{*}{0.774} \\
\hline \multirow[t]{2}{*}{ Late apoptosis } & 3.57 & 4.3 & \\
\hline & $(100 \mathrm{ng} / \mathrm{ml})$ of LPS & $\begin{array}{c}(100 \mathrm{ng} / \mathrm{ml}) \text { of LPS } \\
+(100 \mu \mathrm{g} / \mathrm{ml}) \text { of } \\
\text { P. crispa extract }\end{array}$ & $p$ value \\
\hline Apoptosis & 2.54 & 0.29 & \multirow{2}{*}{0.774} \\
\hline \multirow[t]{2}{*}{ Late apoptosis } & 4.3 & 5.31 & \\
\hline & Control & $\begin{array}{l}(100 \mu \mathrm{g} / \mathrm{ml}) \text { of } \\
\text { P. crispa extract }\end{array}$ & $p$ value \\
\hline Apoptosis & 2.24 & 0.05 & \multirow{2}{*}{0.015} \\
\hline Late apoptosis & 3.57 & 16.48 & \\
\hline
\end{tabular}

MEK expression was absent in LPS-stimulated cells after $P$. crispa extract exposure may explain the observed reduction in NF- $\kappa$ B signaling. Moreover, it has been shown that activation of NF- $\kappa$ B mainly occurs via IKB kinase-mediated phosphorylation of the inhibitory molecule IKB- $\alpha$ [53]. The downregulated NF- $\kappa \mathrm{B}$ expression may explain the observed underexpression of chemotactic factors in the current study [54]. However, to our surprise, $P$. crispa extract increased TNF- $\alpha$ expression in LPS-stimulated and unstimulated cells. Although this would need confirmation in future studies, it may indicate that $P$. crispa extract constituents target other regulatory factors that control the TNF- $\alpha$ expression.

Phagocytosis is a major function of macrophages in the innate immune response against foreign bodies. It is regulated by several cytokines including TNF- $\alpha$ and IL-1 [55]. However, it may be implicated in several chronic inflammatory diseases such as chronic infections, systemic lupus erythematosus, and autoimmune anemia [56]. The present study showed that $P$. crispa extract inhibited the phagocytic activity in LPS-stimulated cells. However, surprisingly, it enhanced phagocytosis in unstimulated THP-1 cells. This differential effect needs to be further confirmed in future studies.

In conclusion, treatment of THP-1 cells with $P$. crispa extract significantly reduced cell migration, proliferation, and phagocytosis in LPS-stimulated cells. Moreover, it significantly reduced the expression of various chemotactic and 
cell survival-related proteins. These results highlight the antiinflammatory and immunomodulatory effects of $P$. crispa extract in LPS-stimulated THP-1 cells. Future studies should investigate these mechanisms in animal models with chronic inflammatory diseases.

\section{Abbreviations}

$\begin{array}{ll}\text { CCL: } & \text { C-C motif chemokine ligand } \\ \text { CXCL: } & \text { C-X-C motif ligand } 2 \\ \text { ERK: } & \text { Extracellular-signal regulated kinase } \\ \text { ICAM: } & \text { Intracellular adhesion molecule } \\ \text { IKB- } \alpha: & \text { Inhibitor kappa B- } \alpha \\ \text { LPS: } & \text { Lipopolysaccharide, } \\ \text { MAPK: } & \text { Mitogen activated protein kinase } \\ \text { TNF: } & \text { Tumor necrosis factor } \\ \text { MФs: } & \text { Macrophages } \\ \text { IL: } & \text { Interleukin } \\ \text { DAMPS: } & \text { Damaged associated molecular patterns } \\ \text { MHC: } & \text { Major histocompatibility complex } \\ \text { ICAM-1: } & \text { Intracellular adhesion molecule } \\ \text { FBS: } & \text { Fetal bovine serum } \\ \text { qRT-PCR: } & \text { Quantitative reverse-transcriptase polymerase } \\ & \text { chain reaction } \\ \text { ELISA: } & \text { Enzyme-linked immunosorbent assay } \\ \text { TMB: } & \text { Tetramethylbenzidine } \\ \text { HRP: } & \text { Streptavidin-horseradish peroxidase } \\ \text { PVDF: } & \text { Polyvinylidene difluoride } \\ \text { HCC: } & \text { Hepatocellular carcinoma. } \\ & \end{array}$

\section{Data Availability}

The data used to support the findings of this study are available from the corresponding author upon request.

\section{Conflicts of Interest}

The authors declare that there is no conflict of interest regarding the publication of this paper.

\section{Authors' Contributions}

AAA and SA conceived and designed the study. TA, MMA, and MRA were responsible for the performance of the experiments. MMA, MRA, and MDA analyzed the data, prepared the figures, and analyzed the data. AAA and SA interpreted the results. TA, MMA, MRA, and MDA helped in writing the preliminary draft of the manuscript. AAA and SA were responsible for revising and approval of the final version of the manuscript.

\section{Acknowledgments}

This research was funded by the Deanship of Scientific Research at Princess Nourah bint Abdulrahman University, through the Research Funding Program (Grant Number: FRP-1440-T).

\section{References}

[1] S. Gordon and L. Martinez-Pomares, "Physiological roles of macrophages," Pflügers Archiv - European Journal of Physiology, vol. 469, no. 3-4, pp. 365-374, 2017.

[2] S. Gordon, "Phagocytosis: the legacy of Metchnikoff," Cell, vol. 166, no. 5, pp. 1065-1068, 2016.

[3] Z. Bar-Shavit, "The osteoclast: a multinucleated, hematopoietic-origin, bone-resorbing osteoimmune cell," Journal of Cellular Biochemistry, vol. 102, no. 5, pp. 1130-1139, 2007.

[4] J. A. Chasis and N. Mohandas, "Erythroblastic islands: niches for erythropoiesis," Blood, vol. 112, no. 3, pp. 470-478, 2008.

[5] R. C. Paolicelli, G. Bolasco, F. Pagani et al., "Synaptic pruning by microglia is necessary for normal brain development," Science, vol. 333, no. 6048, pp. 1456-1458, 2011.

[6] T. Ganz, "Macrophages and systemic iron homeostasis," Journal of Innate Immunity, vol. 4, no. 5-6, pp. 446-453, 2012.

[7] S. E. Headland and L. V. Norling, "The resolution of inflammation: principles and challenges," Seminars in Immunology, vol. 27, no. 3, pp. 149-160, 2015.

[8] M. Hesketh, K. B. Sahin, Z. E. West, and R. Z. Murray, "Macrophage phenotypes regulate scar formation and chronic wound healing," International Journal of Molecular Sciences, vol. 18, no. 7, p. 1545, 2017.

[9] A. Shapouri-Moghaddam, S. Mohammadian, H. Vazini et al., "Macrophage plasticity, polarization, and function in health and disease," Journal of Cellular Physiology, vol. 233, no. 9, pp. 6425-6440, 2018.

[10] Y. Chen and X. Zhang, "Pivotal regulators of tissue homeostasis and cancer: macrophages," Experimental Hematology \& Oncology, vol. 6, no. 1, 2017.

[11] A. Das, M. Sinha, S. Datta et al., "Monocyte and macrophage plasticity in tissue repair and regeneration," The American Journal of Pathology, vol. 185, no. 10, pp. 2596-2606, 2015.

[12] L. Arnold, A. Henry, F. Poron et al., "Inflammatory monocytes recruited after skeletal muscle injury switch into antiinflammatory macrophages to support myogenesis," Journal of Experimental Medicine, vol. 204, no. 5, pp. 1057-1069, 2007.

[13] S. Lee, S. Huen, H. Nishio et al., "Distinct macrophage phenotypes contribute to kidney injury and repair," Journal of the American Society of Nephrology, vol. 22, no. 2, pp. 317-326, 2011.

[14] A. Parihar, T. D. Eubank, and A. I. Doseff, "Monocytes and macrophages regulate immunity through dynamic networks of survival and cell death," Journal of Innate Immunity, vol. 2, no. 3, pp. 204-215, 2010.

[15] S. Deane, C. Selmi, S. S. Teuber, and M. E. Gershwin, "Macrophage activation syndrome in autoimmune disease," International Archives of Allergy and Immunology, vol. 153, no. 2, pp. 109-120, 2010.

[16] D. Watts and A. H. Al-Nafie, Vegetation and biogeography of the sand seas of Saudi Arabia, Kegan Paul, 2003.

[17] A. I. Foudah, A. Alam, G. A. Soliman, M. A. Salkini, E. O. Ibnouf Ahmed, and H. S. Yusufoglu, "Pharmacognostical, Antioxidant and Antimicrobial Studies of Aerial Part of Pulicaria Crispa (Family: Asteraceae)," Bulletin of Environment, Pharmacology and Life Sciences, vol. 4, no. 12, pp. 19-27, 2015.

[18] A. A. Fahmi, M. Abdur-Rahman, A. F. Aboul Naser et al., "Chemical composition and protective role of Pulicaria undulata (L.) C.A. Mey. subsp. undulata against gastric ulcer 
induced by ethanol in rats," Heliyon, vol. 5, no. 3, article e01359, 2019.

[19] M. A. alo Yahya, A. M. el-Sayed, J. S. Mossa et al., "Potential cancer chemopreventive and cytotoxic agents from Pulicaria crispa," Journal of Natural Products, vol. 51, no. 3, pp. 621$624,1988$.

[20] Y. H. Elshiekh and M. A. AbdElMoniem, "Phytochemical, antibacterial screening and antioxidant activity of Pulicaria crispa extracts," The Pharma Innovation, vol. 3, no. 12, pp. 12-15, 2015.

[21] A. Adebiyi, E. Bassey, R. Ayo, I. Bello, J. Habila, and G. Ishaku, "Anti-mycobacterial, antimicrobial and phytochemical evaluation of Pulicaria crispa and Scoparia dulcis plant extracts," Journal of Advances in Medical and Pharmaceutical Sciences, vol. 7, no. 4, pp. 1-11, 2016.

[22] Y. H. Elshiekh and A. Mona, "Gas chromatography-mass spectrometry analysis of Pulicaria crispa (whole plant) petroleum ether extracts," American Journal of Research Communication, vol. 3, no. 3, pp. 58-67, 2015.

[23] V. Kuete, B. Wiench, M. S. Alsaid et al., "Cytotoxicity, mode of action and antibacterial activities of selected Saudi Arabian medicinal plants," BMC Complementary and Alternative Medicine, vol. 13, no. 1, 2013.

[24] A. S. Maghraby, N. Shalaby, H. I. Abd-Alla, S. A. Ahmed, H. M. Khaled, and M. M. Bahgat, "Immunostimulatory effects of extract of Pulicaria crispa before and after Schistosoma mansoni infection," Acta Poloniae Pharmaceutica, vol. 67, no. 1, pp. 75-79, 2010.

[25] M. M, A. MM, E. EH, W. SE, and M. SE, "In vitro antileishmanial activity of Helianthus annuus and Pulicaria crispa (Asteraceae)," Natural Products Chemistry \& Research, vol. 5, no. 4, p. 2, 2017.

[26] A. H. Arbab, M. K. Parvez, M. S. al-Dosari, and A. J. al-Rehaily, "In vitro evaluation of novel antiviral activities of 60 medicinal plants extracts against hepatitis B virus," Experimental and Therapeutic Medicine, vol. 14, no. 1, pp. 626634, 2017.

[27] A. A. Alghaithy, H. A. el-Beshbishy, A. AbdelNaim, A. A. Nagy, and E. M. Abdel-Sattar, "Anti-inflammatory effects of the chloroform extract of Pulicaria guestii ameliorated the neutrophil infiltration and nitric oxide generation in rats," Toxicology and Industrial Health, vol. 27, no. 10, pp. 899910, 2011.

[28] P. Hunter, "The inflammation theory of disease. The growing realization that chronic inflammation is crucial in many diseases opens new avenues for treatment," EMBO Reports, vol. 13, no. 11, pp. 968-970, 2012.

[29] Z. D. Hu, T. T. Wei, Q. Q. Tang et al., "Gene expression profile of THP-1 cells treated with heat-killed Candida albicans," Annals of Translational Medicine, vol. 4, no. 9, 2016.

[30] H. Bosshart and M. Heinzelmann, "THP-1 cells as a model for human monocytes," Annals of Translational Medicine, vol. 4, no. $21,2016$.

[31] S. Tedesco, F. de Majo, J. Kim et al., "Convenience versus biological significance: are PMA-differentiated THP-1 cells a reliable substitute for blood-derived macrophages when studying in vitro polarization?," Frontiers in Pharmacology, vol. 9, no. 71, 2018.

[32] P. Wangchuk, P. A. Keller, S. G. Pyne, and M. Taweechotipatr, "Inhibition of TNF- $\alpha$ production in LPS-activated THP-1 monocytic cells by the crude extracts of seven Bhutanese medicinal plants," Journal of Ethnopharmacology, vol. 148, no. 3, pp. 1013-1017, 2013.

[33] S. S. Choudhury, L. Bashyam, N. Manthapuram, P. Bitla, P. Kollipara, and S. D. Tetali, "Ocimum sanctum leaf extracts attenuate human monocytic (THP-1) cell activation," Journal of Ethnopharmacology, vol. 154, no. 1, pp. 148-155, 2014.

[34] L. Allen-Hall, P. Cano, J. T. Arnason, R. Rojas, O. Lock, and R. M. Lafrenie, "Treatment of THP-1 cells with Uncaria tomentosa extracts differentially regulates the expression if IL-1 $\beta$ and TNF- $\alpha$," Journal of Ethnopharmacology, vol. 109, no. 2, pp. 312-317, 2007.

[35] J. Balsinde, B. Fernández, J. A. Solís-Herruzo, and E. Diez, "Pathways for arachidonic acid mobilization in zymosanstimulated mouse peritoneal macrophages," Biochimica et Biophysica Acta (BBA) - Molecular Cell Research, vol. 1136, no. 1, pp. 75-82, 1992.

[36] L. Gil-de-Gómez, A. M. Astudillo, C. Meana et al., "A phosphatidylinositol species acutely generated by activated macrophages regulates innate immune responses," The Journal of Immunology, vol. 190, no. 10, pp. 5169-5177, 2013.

[37] D. M. Mosser and J. P. Edwards, "Exploring the full spectrum of macrophage activation," Nature Reviews. Immunology, vol. 8, no. 12, pp. 958-969, 2008.

[38] I. Tabas, "Macrophage death and defective inflammation resolution in atherosclerosis," Nature Reviews. Immunology, vol. 10, no. 1, pp. 36-46, 2010.

[39] M. G. Dorrington and I. D. Fraser, "NF- $\kappa$ B signaling in macrophages: dynamics, crosstalk, and signal integration," Frontiers in Immunology, vol. 10, 2019.

[40] G. E. Jones, "Cellular signaling in macrophage migration and chemotaxis," Journal of Leukocyte Biology, vol. 68, no. 5, pp. 593-602, 2000.

[41] N. H. Bergman, K. D. Passalacqua, R. Gaspard, L. M. ShetronRama, J. Quackenbush, and P. C. Hanna, "Murine macrophage transcriptional responses to Bacillus anthracis infection and intoxication," Infection and Immunity, vol. 73, no. 2, pp. 1069-1080, 2005.

[42] M. A. Emam, H. I. Khattab, and M. G. Hegazy, “Assessment of anticancer activity of Pulicaria undulata on hepatocellular carcinoma HepG2 cell line," Tumour Biology, vol. 41, no. 10, 2019.

[43] G. N. Nithianandarajah-Jones, B. Wilm, C. E. P. Goldring, J. Müller, and M. J. Cross, "ERK5: structure, regulation and function," Cellular Signalling, vol. 24, no. 11, pp. 2187-2196, 2012.

[44] R. Aoidi, A. Maltais, and J. Charron, "Functional redundancy of the kinases MEK1 and MEK2: rescue of the Mek1 mutant phenotype by Mek2 knock-in reveals a protein threshold effect," Science Signaling, vol. 9, no. 412, 2016.

[45] M. Fu, C. Wang, Z. Li, T. Sakamaki, and R. G. Pestell, "Minireview: Cyclin D1: normal and abnormal functions," Endocrinology, vol. 145, no. 12, pp. 5439-5447, 2004.

[46] R. Roskoski Jr., "ERK1/2 MAP kinases: structure, function, and regulation," Pharmacological Research, vol. 66, no. 2, pp. 105-143, 2012.

[47] B. Wang, H. Jiang, N. Ma, and Y. Wang, "Phosphorylated-p38 mitogen-activated protein kinase expression is associated with clinical factors in invasive breast cancer," Springerplus, vol. 5, no. 1, 2016.

[48] T. M. Thornton and M. Rincon, "Non-classical p38 map kinase functions: cell cycle checkpoints and survival," 
International Journal of Biological Sciences, vol. 5, no. 1, pp. 44-52, 2009.

[49] T. Jin, X. Xu, and D. Hereld, "Chemotaxis, chemokine receptors and human disease," Cytokine, vol. 44, no. 1, pp. 1-8, 2008.

[50] L. Yang, R. M. Froio, T. E. Sciuto, A. M. Dvorak, R. Alon, and F. W. Luscinskas, "ICAM-1 regulates neutrophil adhesion and transcellular migration of TNF- $\alpha$-activated vascular endothelium under flow," Blood, vol. 106, no. 2, pp. 584-592, 2005.

[51] D. M. Pereira, S. E. Gomes, P. M. Borralho, and C. M. P. Rodrigues, "MEK5/ERK5 activation regulates colon cancer stemlike cell properties," Cell Death Discovery, vol. 5, no. 1, 2019.

[52] M. M. Kloster, E. H. Naderi, H. Carlsen, H. K. Blomhoff, and S. Naderi, "Hyperactivation of NF- $\kappa \mathrm{B}$ via the MEK signaling is indispensable for the inhibitory effect of cAMP on DNA damage-induced cell death," Molecular Cancer, vol. 10, no. 1, 2011.

[53] P. Viatour, M. P. Merville, V. Bours, and A. Chariot, "Phosphorylation of NF- $\kappa \mathrm{B}$ and $\mathrm{I} \kappa \mathrm{B}$ proteins: implications in cancer and inflammation," Trends in Biochemical Sciences, vol. 30, no. 1, pp. 43-52, 2005.

[54] M. Penzo, D. M. Habiel, M. Ramadass, R. R. Kew, and K. B. Marcu, "Cell migration to CXCL12 requires simultaneous IKK $\alpha$ and IKK $\beta$-dependent NF- $\kappa \mathrm{B}$ signaling," Cell Research, vol. 1843, no. 9, pp. 1796-1804, 2014.

[55] G. Arango Duque and A. Descoteaux, "Macrophage cytokines: involvement in immunity and infectious diseases," Frontiers in Immunology, vol. 5, 2014.

[56] D. Hirayama, T. Iida, and H. Nakase, "The phagocytic function of macrophage-enforcing innate immunity and tissue homeostasis," International Journal of Molecular Sciences, vol. 19, no. 1, 2018. 